University of Nebraska - Lincoln

DigitalCommons@University of Nebraska - Lincoln

Faculty Publications: Department of Teaching, Department of Teaching, Learning and Teacher Learning and Teacher Education

Education

2020

\title{
Googly eyes and yard signs: Deconstructing one professor's successful rebuffing of a right-wing attack on an academic institution
}

\author{
Theresa Catalano \\ University of Nebraska-Lincoln, tcatalano2@unl.edu \\ Ari Kohen \\ University of Nebraska-Lincoln, akohen2@unl.edu
}

Follow this and additional works at: https://digitalcommons.unl.edu/teachlearnfacpub

Part of the American Politics Commons, Communication Technology and New Media Commons, Critical and Cultural Studies Commons, Curriculum and Instruction Commons, Other Public Affairs, Public Policy and Public Administration Commons, Social Influence and Political Communication Commons, and the Teacher Education and Professional Development Commons

Catalano, Theresa and Kohen, Ari, "Googly eyes and yard signs: Deconstructing one professor's successful rebuffing of a right-wing attack on an academic institution" (2020). Faculty Publications: Department of Teaching, Learning and Teacher Education. 369.

https://digitalcommons.unl.edu/teachlearnfacpub/369

This Article is brought to you for free and open access by the Department of Teaching, Learning and Teacher Education at DigitalCommons@University of Nebraska - Lincoln. It has been accepted for inclusion in Faculty Publications: Department of Teaching, Learning and Teacher Education by an authorized administrator of DigitalCommons@University of Nebraska - Lincoln. 


\title{
Googly eyes and yard signs: Deconstructing one professor's successful rebuffing of a right-wing attack on an academic institution
}

\author{
Theresa Catalano \\ Ari Kohen
}

University of Nebraska-Lincoln, USA

Corresponding author - Theresa Catalano, Department of Teaching, Learning and Teacher Education, University of Nebraska-Lincoln, 118 Henzlik Hall, Lincoln, NE 68588, USA. Email tcatalano2@unl.edu

\begin{abstract}
Right-wing populism is on the rise worldwide, and political attacks against universities have increased in the United States since the election of Donald Trump. In 2017, an incident occurred at the University of Nebraska-Lincoln which resulted in accusations of hostility toward conservative students. Just over a year later, political forces again attempted to denigrate the university's reputation, but this time they did not succeed. This (multimodal) positive discourse analysis/ generative critique combines collaborative auto-ethnography to describe the way these events were represented in the media, deconstructing a professor's methods of countering a rightwing attack on an academic institution. Findings demonstrate the use of multiple strategies such as controlling the narrative through social media savvy; using linguistic strategies such as refutation of strawman fallacies, syntax, deixis and emotional appeal; and use of image.
\end{abstract}

Keywords: Anti-intellectualism, collaborative auto-ethnography, generative critique, positive discourse analysis, right-wing populism

Published in Discourse \& Society (2019)

DOI: $10.1177 / 0957926519880037$

Copyright (C) 2019 Theresa Catalano \& Ari Kohen; published by SAGE Publications. Used by permission. 


\section{Introduction}

On 28 August 2017, a University of Nebraska-Lincoln (UNL) undergraduate student set up a recruitment table for Turning Point USA (a right-wing conservative organization which features a Professor Watchlist) on the campus. Members of the UNL community, including a graduate student/teaching assistant and faculty member in the English Department, protested nearby. Part of the protest (which included profanity and namecalling) was recorded on video and released to social media. Social media coverage then led to harsh public criticism (including from conservative state senators) that publicly accused the university of restricting free speech and being an unsafe environment for conservative students. Initially, the graduate student/teaching assistant was put on leave for her own 'safety', but after pressure from three state senators, she was removed from her position as a teacher, which resulted in UNL being censured by the American Association of University Professors (AAUP), a status it currently still holds (for more on this, see Fucci and Catalano, 2019).

Just over a year after these events, right-wing politicians from Nebraska tried again to advance the narrative that UNL is hostile to conservatives. This time, they targeted UNL professor Ari Kohen for liking a Facebook post which showed a photograph of a vandalized campaign yard sign (googly eyes and references to flatulence, for example, Fartenberry, odor had been added) for Congressman Jeffrey Fortenberry. Below is the photo that Kohen liked:

See original photo here: https://www.rollingstone.com/politics/politics-news/ fortenberry-googly-eyesvandalism- professor-751618/

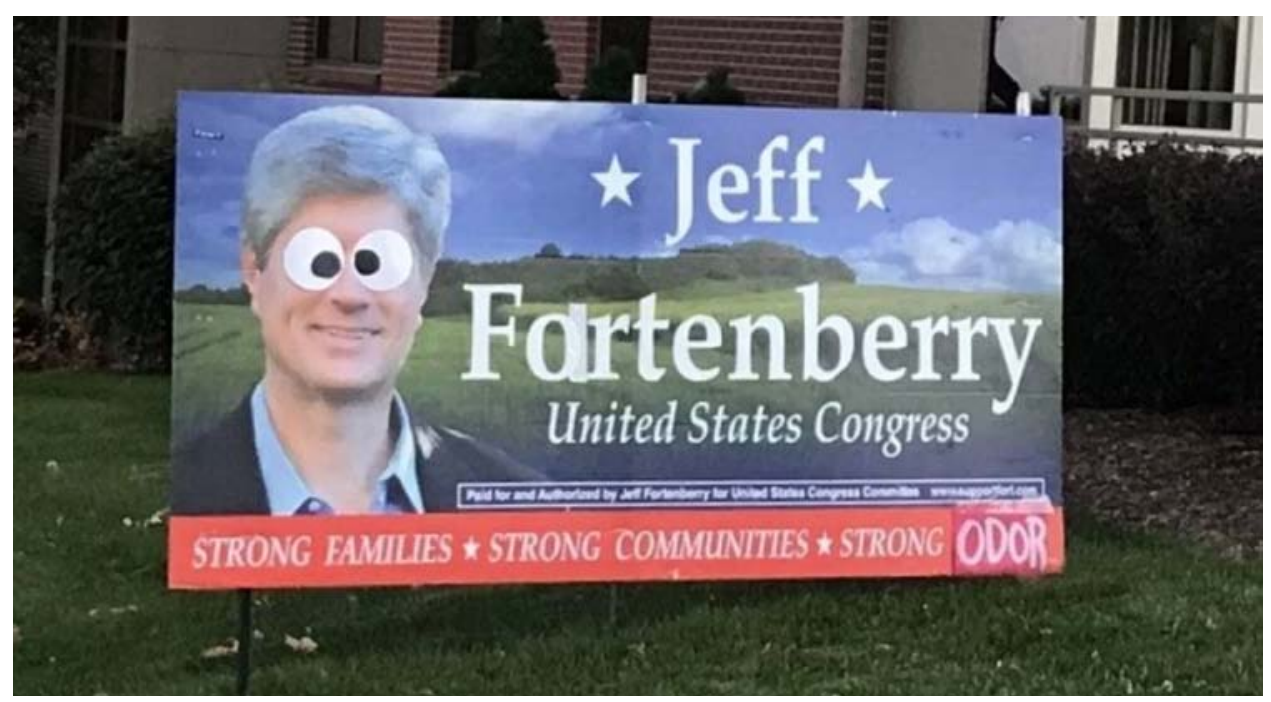


Days after liking the photo on his cell phone screen, Kohen spoke with Dr William 'Reyn' Archer III, Chief of Staff for Congressman Fortenberry. The phone call lasted 53 minutes and was recorded by Kohen ${ }^{1}$ who made selected excerpts available to the press and online. Archer accused Kohen of 'liking vandalism' and threatened to use his office to make that claim public, essentially putting Kohen and, by extension, the university, in hot water. However, this time, Kohen, then president of UNL's chapter of the AAUP, tenured professor of political science (and human rights, heroism, and restorative justice scholar), and widely read blogger, was ready. Through the use of a number of effective strategies, Kohen successfully rebuffed the politician and his staff, resulting in no negative consequences for the university, but a damaged reputation for the congressman and his staffer due to a complaint he filed with the Office of Congressional Ethics and the resultant negative press. This article incorporates (multimodal) positive discourse analysis (PDA)/generative critique with the aim of documenting successful academic pushback against anti-intellectualism and right-wing populism (RWP), using Kohen's situation as an example. We also employ collaborative auto-ethnography (CAE), using discussions between Kohen and the first author (Catalano) to complement and provide context and insider perspectives on why Kohen did what he did. In order to give some context for understanding our analysis, the next section provides a brief overview of RWP and its link to anti-intellectualism.

\section{Anti-intellectualism and RWP}

According to Zakaria (1997: 23-24), 'illiberal democracies' (e.g. rightwing populist governments), which increasingly limit the freedoms of the people they represent, are increasing around the world (Wodak, 2019: 199). RWP is a 'hybrid political ideology that rejects the postwar political consensus and usually, though not always, combines laissez-faire liberalism and anti-elitism with other, often profoundly different and contradictory ideologies' (Wodak and Krzyżanowski, 2017:

1. This is not the first time Archer has been in trouble after having his conversations recorded. In 2000, he resigned from his then job as Texas health commissioner after having his recorded conversation with former employee Demetria Montgomery released to the public. In the conversation, Archer made several racist comments (Vertuno, 2000). 
475). RWP is called 'populism' because it appeals to a homogenized common man or woman, and it grows out of 'public pessimism, anxiety, and disaffection' of 'the people' (Betz, 1994: 41). In this 'postshame' era in which RWP reigns and far-right ideologies have become normalized, antielitist (along with anti-pluralist/exclusionary) rhetoric supports the 'shamelessness, humiliation of other participants, defamation, lies and ad hominem attacks' of 'powerful politicians that frequently resonate as "authentic" with the core followers of these politicians, their parties or governments' (Wodak, 2019: 197).

'Intellectuals have been ridiculed and chastised since ancient times' (Siniver, 2016: 631) and scholars such as Hofstadter (1963) have argued that 'anti-intellectualism is part of the fabric of American society, a product of evangelism, primitivism, business activism and egalitarianism' (p. 22). It is also an important element of RWP (Wodak, 2019: 198) and is 'a pervasive social phenomenon which transcends temporal and spatial boundaries' (Siniver, 2016: 630). Anti-intellectualism (and anti-elitism in general) is based on the construction of the dichotomy of 'real' and 'true' people versus the 'elites' or 'the establishment' who are distinct from the common people (Wodak, 2017: 553). Who exactly are considered the 'elites' varies from country to country. In the United States, the rich are not necessarily part of the 'elites' (since everybody could possibly become rich), but intellectuals (including scholars and teachers) are seen as dangerous, along with journalists and the politically powerful (Wodak, 2017: 555-557). The way RWP connects to anti-intellectualism is through a political rhetoric which aims to divide the people into two camps, 'the people' against 'the establishment'. Since intellectuals (by being a source of knowledge and information but also generally tending to be progressive rather than conservative, politically) fit into 'the establishment', anti-intellectual discourses seek to foster public distrust in universities as a whole.

One strategy of the right-wing in the United States has been to provoke situations that can be used to demonstrate that universities are against conservatives (Scott, 2017: 5). This has been accomplished by creating traps for university professors to fall in (e.g. a professor makes a comment publicly or in class that demonstrates his or her left-leaning political views which is filmed by a conservative student and then shared to viral effect on social media; cf. Fucci and Catalano, 2019). Conservative politicians and groups weigh in on the situation, 
and the actions of one professor are then highly publicized and extrapolated to represent the university as a whole. This provides supposed evidence that universities are hostile to conservatives. The 'googly eyes' events fit neatly into this description of right-wing 'traps' described above.

\section{RWP, social media and free speech}

\section{RWP and social media}

RWP, along with other types of political and social movements, has benefited from the use of social media. Social media increase the potential for hate speech just by its wide distribution around the globe and also can 'create a sense of community without the constraining influence of communities in real space' and thus increase the possibility that a 'nameless, faceless audience member seeking support for his violent plans can find it online' (Lidsky, 2011:163). According to Krzyżanowski and Tucker (2018),

the growth of the political use of social media has, accordingly, also been viewed as one of the central factors in not only the further celebrification of politics (cf. Donald Trump) but also in the ensuing - and currently still ongoing - reemergence and success of (right-wing) populist politics in Europe and the USA in the second decade of 2000 (p. 14).

Numerous studies have reported the use of social media to express and spread false information and repeat nativist and nationalist populist propaganda (e.g. Wodak, 2015). In this right-wing discourse, 'the mechanism of "scapegoating" (singling out a group for negative treatment on the basis of collective responsibility) constitutes an important feature' (Wodak, 2017: 553) and this type of discourse 'always combines and integrates form and content, targets specific audiences, and adapts to specific contexts'. Hence, social media (or social networking sites (SNSs)) provide the perfect space for these discourses to occur.

Besides providing a space for right-wing discourses to thrive, research has shown how social media can be used as a form of activism or resistance. For example, Mortensen (2011) studied the 2009 
uprising in Iran highlighting the way in which social media empowered people to share information and make it more difficult to keep violent acts by governments hidden and at the same time recognizing the limits of social media (especially because it is not available to everyone) and its potential to be used as a government tool to monitor and control citizens. Kelsey and Bennett (2014) described the way that Twitter was used to mobilize resistance against the state and to show support for an individual who previously lacked power, whereas Custodio (2014) explored offline dimensions of online actions protesting human rights violations before the 2016 Summer Olympics. This study builds on this research exploring the role of social media in resistance from an auto-ethnographic angle.

\section{Freedom of speech}

Freedom of speech is 'the right to express one's ideas, however true or false they may be' (Scott, 2017), as enshrined in the First Amendment. This should not be confused with academic freedom, which protects faculty rights to engage in intellectual discussions or debates without fear of censorship or retaliation:

The First Amendment generally, and freedom of expression in particular, are not absolute concepts, and that is why they are at once so difficult to administer and so essential to a free society and an educated citizenry. (Hudson, 2018, last para.)

Because of the important intellectual work of discussion and debate, 'public universities are particularly rich grounds for conflict over matters of speech' (Hudson, 2018, second para.). However, this does not mean that political propaganda in the classroom or discrimination against students because of political beliefs is protected. Nonetheless, organizations such as the AAUP strongly contend that 'where questions arise concerning the propriety of conduct of a faculty member, the matter should be referred to appropriate faculty bodies at the faculty member's institution' (Tiede, 2017, sixth para.), something that did not happen in the case at UNL described above (Fucci and Catalano, 2019).

In recent years, the Supreme Court (under Chief Justice John G Roberts Jr.) 'has been more likely to embrace free speech arguments 
concerning conservative speech than liberal speech', which is in contrast to earlier time periods (Liptak, 2018, eighth para.). Moreover, speech has become a 'weapon' of the Right (Scott, 2017: 3). One example of this can be seen in Fucci and Catalano (2019), in which politicians accused faculty of being hostile to conservatives and arguing that political actions of professors are not protected by free speech. This is true also of this article, in which conservative politicians argue that a professor's 'likes' on Facebook constitute negative actions against a conservative politician and the criminal act of vandalism itself.

Social media/SNSs and university professors

SNSs, like Facebook, constitute a space in which university professors (and teachers in general) can interact with the general public, which sometimes includes their students or colleagues. This 'contributes to a blurring of boundaries between professional and personal personas' (Sugimoto et al., 2015: 1) and the creation of novel issues related to the communication of ideas that could be considered offensive or wrong. In addition,

faculty profiles on SNSs or other types of social media through which they communicate, such as blogs, may list the institution with which they are affiliated, together with rank or status. Questions then arise whether or not the faculty member is enacting a professional or personal role on these sites and through these media. (Sugimoto et al., 2015: 8)

Likes, comments and shares constitute various degrees of political engagement on social media, and in many cases, 'controversies over faculty activities have led to threats of physical violence against individual faculty members or the institution' (Tiede, 2017, fifth para.).

There are many examples of inappropriate conduct/communication on social media from faculty members (e.g. Blackford, 2011; Kingkade, 2013; Miller, 2010), and 'public reaction to these messages suggests that new expectations have developed around the public presentation of faculty members in the online space' (Sugimoto et al., 2015: 9). Different universities have taken different actions in response to these situations varying from public apologies to suspension and censure, and it is clear that standards related to social media participation of 
faculty are not yet fully developed. As such, organizations such as the AAUP have recommended faculty and students 'engage in open dialogue about norms of behavior; expressing the expectations and values of both groups' (Sugimoto et al., 2015:10). They also argue that 'social media policies at institutions of higher education are therefore not so much for the individuals associated with the institution, as they are for the institution itself' (Sugimoto et al., 2015: 10). In the case of Kohen, who merely 'liked' a humorous photograph on Facebook, and did so as a private citizen, not as a faculty employee, the First Amendment does clearly protect his actions (Stein, 2013). And, unlike the events of the previous year described in Fucci and Catalano (2019), university administrators did not act on Kohen's situation in any way, since it did not involve the university (other than his being employed there). However, social media situations are not always this clear, and it is important to note that much work still needs to be done in clarifying the First Amendment and its relation to university faculty's use of social media as it connects to free speech.

\section{Method}

\section{Multimodal PDA/generative critique}

In order to examine the way in which the discourse of Kohen (as represented in the media) is constructive as opposed to de-constructive, we employ a multimodal form of PDA (Martin, 2004) or generative critique which examines social change that is happening and is 'oriented to equality and heterogeneous well-being' (Haraway, 1997: 95, as cited in Macgilchrist, 2016: 273). Although the analysis will look at the ways in which power is enacted by powerful groups (e.g. local politicians), our main focus is on the way that Kohen used language (and multimodal modes of communication such as Twitter and image) to resist the powers attempting to threaten him (and the university). PDA was born out of critique of critical discourse analysis (CDA, now often referred to as critical discourse studies or CDS) calling for it to 'focus on community, taking into account how people get together and make room for themselves in the world - in ways that redistribute power ...' (Martin, 2004: 6). Within the field of CDA/CDS, scholars 
such as Wodak disagree that PDA is anything different from CDA/ CDS, arguing that being critical is not about being positive or negative, it is about questioning the extant social order and aiming for positive change (personal communication, 11 March 2018). In addition, Macgilchrist (2016: 273) re-frames PDA in terms of post-foundational thinking which has the potential to address 'unequal power relations through (fine-grained) analysis of hope-giving, reparative discourse' (Macgilchrist, 2016: 262). Hence, for our study, we use 'PDA' to emphasize our focus on documenting positive change and resistance to abuses of power as it happens.

Finally, we heed the call for the voices of the 'oppressed' to be heard and for a comparison of the findings of the analyst with what the members of the target community think and say. As such, we incorporate CAE, which we explain in the next section.

\section{$C A E$}

As mentioned above, scholars in the field of CDS have continued to push for the addition of ethnographic approaches in response to its problem of disconnect between the researcher, producer and readers of texts. Ethnographic approaches represent a distinct way to analyze language in culture (among other things) and assist in exploring the 'beliefs, values, and desires' of participants (Chouliaraki and Fairclough, 1999: 62). Various scholars have been combining CDS and ethnographic approaches for a number of years (e.g. Chouliaraki and Fairclough, 1999; Rogers, 2002; Wodak, 1996, 2009) In fact, in the 2011 special issue of Critical Discourse Studies, authors address the combination of CDS with ethnographic studies from a range of topics, and Krzyżanowski's (2011) introduction to the issue recognizes the vital link between ethnography and CDS in providing a more in-depth analysis of societal issues. Machin and Mayr (2012) also advocate for adding an ethnographic dimension to the analysis of newspaper discourse, which can mean interviewing editors and journalists about their choices. In addition, Baroni and Mayr (2017) and Mayr (2018) have used ethnography to show how disenfranchised people resist and make positive change in their communities.

In the case of our article, we employ CAE in order to include Kohen's perspective in the analysis, which he was also involved in writing. CAE 
is autobiographical and engages multiple authors who are also the participants (Chang et al., 2016). For this article, both authors engage in collaboration through discussions and question/answer sessions regarding the accuracy of the analysis and Kohen's thoughts on the strategies behind his successful rebuffing of right-wing politicians. These discussions then inform the analysis, making it nuanced and more accurate. This is because Kohen understands better than anyone how he successfully combatted this anti-intellectual attack, and also Catalano has the background in CDS needed to help articulate linguistic and visual elements behind the discourse. In dialoging together, we engage in the self-reflexive examination of our own assumptions and perspectives and use the researcher's personal experiences as primary data (Chang et al., 2016) along with the media discourse in which his experiences are represented. Because the researchers in this study are also the participants, institutional review board approval was not necessary.

\section{Data collection}

In addition to collaborative auto-ethnographic discussions of Kohen's experiences related to his liking a post on Facebook, we examined 18 articles (including three videos and original tweet threads from Kohen) which represented the related events. All articles fit the following criteria:

1. Local/regional or national news report about the 'googly eyes' events.

2. Must be 500 words or more.

3. Must contain multimodal data and not just text or just image.

Articles were found using the search term 'Ari Kohen' + 'googly eyes' or 'Fartenberry'. All articles were published between the dates of 1 November and 6 November 2018 and were found in local/regional or national news reports of various political tendencies (e.g. Omaha World Herald (right-center), Lincoln Journal Star (neutral), Washington Post (left-center) and MSNBC (left)). ${ }^{2}$

2. Media bias was determined using mediabiasfactcheck.com 


\section{Data analysis}

Articles (including tweets, but not image and video) were compiled into one .txt file and uploaded to MAXQDA, ${ }^{3}$ which was used to check word frequencies and thematically code data (Saldana, 2015) using pre-determined thematic codes based on a first reading and also adding in-vivo coding when new themes were determined. Themes were selected based on strategies used by Kohen to combat his accusers. In addition to the verbal file, images and videos were also collected into one file. The authors employed techniques from (multimodal) CDS for the analysis of visual and verbal data. The following three themes emerged after analysis: Controlling the Narrative, Attending to Language and Image (see Findings section below). As part of this multilayered analysis, the authors came together after the initial draft was written up (Catalano wrote first draft and Kohen revised and made changes) to discuss the analysis. During this collaborative discussion, which occurred on 26 February 2019 (and in subsequent follow-up emails), Catalano asked Kohen a series of questions based on the initial analysis. Kohen answered the open-ended questions, but this also led to a wider discussion. This discussion was recorded with the Quick Voice Pro app on Catalano's cell phone. Salient findings from this discussion (such as Kohen's personal perspective on the analysis) are included verbatim (or in summary form) in the findings section.

\section{Findings}

\section{Controlling the narrative}

The first venue where the incident was represented was in Kohen's interview with Chris Dunker at the Lincoln Journal Star. Kohen's side of the story was featured first, and he utilizes many strategies we will point out later, but his first (multimedia) strategy was to post a link to the article on his Twitter page, along with a series of tweets about the events that also included a link to his phone conversation with 
Archer on YouTube. He then copied all his tweets into one Facebook post and published that as well.

Kohen was thoughtful about his use of social media when he published his tweets (and Facebook post) related to the phone call with William 'Reyn' Archer III (herein referred to as 'Archer'), knowing that his large number of influential followers would share them and spread news of the incident widely. Hence, he harnessed the power of social media (i.e. Twitter and Facebook) by getting his version of the events out before anyone had a chance to hear Archer's perspective. While this might seem like a simple strategy and common sense, it often does not happen (cf. Fucci and Catalano, 2019) because the subjects of these attacks are often blindsided by their escalation.

Kohen remarked in our conversations that had the incident with Turning Point not occurred the year before, he would not have known 'in any sort of firsthand way what a kind of machine there was to gin up controversy'. But, having actually seen how the narrative played out, and became 'like a snowball going downhill', this got him thinking about 'how getting a story out impacts how it will be perceived'. In addition, because of the Turning Point events of the previous year, he was well aware that 'the way the story comes out from the jump, that's how the story is going to go', and he says that knowing what their intention was and what they wanted to do with this information 'really allowed me to think about how to put my narrative out and, in effect, undercut what they wanted to do'.

Cognitive linguists such as George Lakoff have long held that 'messaging is about thinking, not just language' (Lakoff and Wehling, 2012: 3). That is, in order to get language right, you have to understand the thoughts the language provokes. One important lesson from this field is that it is important not just to tell the truth and give the facts, but how this is framed can make a difference. 'It is impossible to communicate without activating frames, and so which frame is activated is of crucial importance' (Lakoff, 2006: 10), and the first frame we are exposed to is what is activated. Hence, when we say 'Don't think of an elephant', the first thing that happens in our brains is that we imagine an elephant in our heads (Lakoff, 2014). In the case of the 'googly eyes' events, it was important for Kohen to activate frames related to Archer's inappropriate actions first, so that this would be what people remembered and thought of when reading about the events. This was 
accomplished successfully by his initial interview with Chris Dunker from the Lincoln Journal Star and then linking the Dunker article to his first tweets about the events (and his Facebook posts, including a link to the phone conversation), as well as in subsequent interviews.

Kohen commented in his conversation with Catalano that he recognized that it was very important to reach journalists first. Because Kohen is a seasoned blogger who used to do weekly podcasts, he already had a microphone and the necessary equipment to record the phone conversation when he spoke to Archer. In addition, he used his Twitter account in which he has a large (and growing) number of followers - many of whom are university professors, journalists and even politicians - to release information about the hour-long phone call with Archer before Archer had a chance to reach out to the press. Moreover, before he tweeted extensively, he filed a formal complaint with the Office of Congressional Ethics and consulted with the UNL AAUP chapter. Kohen also noted in our discussion that he was aware that the first tweet in the thread 'had to grab people, and it did', and also 'it was massively multiplied out into the world and eventually seen by more than 300,000 people'. He also said that he knew that it was not only important to get the message out, but to get it to the right people. The initial tweet in Kohen's thread reached more than 300,000 people; a tweet farther down in that thread, which contained a link to an excerpt from the recorded call, reached 72,00o people. Of those, 1700 clicked through to hear the audio on YouTube. However, of those listeners, many included journalists such as Chris Hayes who ended up featuring it on his popular MSNBC show. Hence, Kohen emphasizes that 'framing matters, as does hitting the right audience!'

\section{Attending to language}

Obviously, when controlling the narrative, the language used to talk about the events is key. In this section, we analyze his tweets and conversation with Archer that point to the use of a number of linguistic strategies used to get his story across and rebuff Archer's accusations.

Again, in alignment with Lakoff's (2014) work regarding frame activation, Kohen presented Archer's negative actions clearly first (so that these would be remembered by readers/ viewers), followed by a simple statement and justification of his own actions, and a repetition 
of Archer's actions. Below, we illustrate how this was done in several of Kohen's tweets: 4

Example (1)

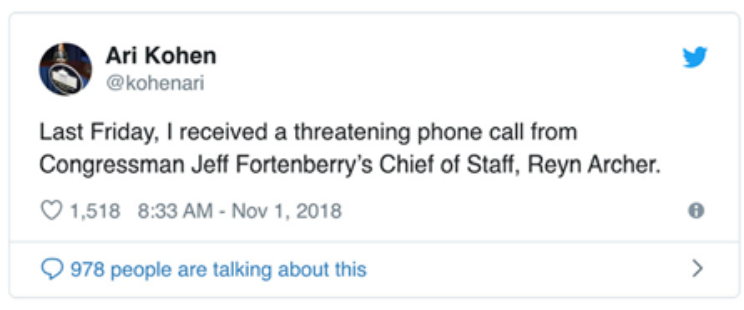

Last Friday, I received a threatening phone call from Congressman Jeff Fortenberry's Chief of Staff, Reyn Archer.

\section{Retweets 1,580 Likes}

(Gettys, 2018)

Example (2)

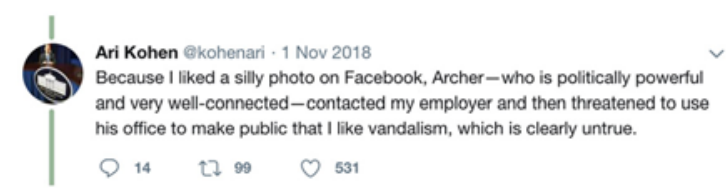

Because I liked a silly photo on Facebook, Archer - who is politically powerful and very wellconnected - contacted my employer and then threatened to use his office to make public that I like vandalism, which is clearly untrue.

\section{4 replies 104 retweets 545 likes}

(Weiner, 2018)

Several elements are worth pointing out in the above tweets. First, Kohen uses honorifics (official titles that suggest a degree of respect, cf. Machin and Mayr, 2012) and functionalization (when social actors are referred to in terms of an occupation or role; Van Leeuwen, 2008) with the statement Congressman Jeff Fortenberry's Chief of Staff, Reyn Archer. Alternatively, Kohen could have just said he received a threatening call from Reyn Archer. However, it was important 
that he identified his connection to Fortenberry while conveying the power and authority that Archer had via his relationship to Fortenberry. In the second tweet, Kohen forefronts and simplifies his own actions (through syntax, aka placing the clause Because I liked a silly photo on Facebook first) and then names Archer and highlights his power and influence with the clause who is politically powerful and very-well connected. Through the possessive his combined with office, he uses deixis to employ relational identification (Van Leeuwen, 2013) drawing attention to Archer's role as a public official (or his connection to that of Fortenberry). He then ends the tweet by negating the accusation of liking vandalism (e.g. which is clearly untrue). Example (2) demonstrates a textbook case of exactly the way in which Lakoff recommends handling right-wing attacks (American Freedom Radio, 2016). That is, first state what actually happened (not the distorted version presented by the opposition), then state what the accusers are saying or doing, then negate the accusations. Often, people start their defense by negating the accusations against them. However, according to what we know about the brain, this just activates negative frames since we are repeating the negative accusations first, and they will stay activated.

It is also worth reiterating here the large number of likes and retweets that each of his tweets received (see beneath each tweet, and also, this number continues to grow), because this demonstrates the power of social media in spreading the narrative that Kohen wanted people to hear first. Within seconds, thousands of people were able to read this and follow the situation, and within 24 hours, news of the events had spread to national news sources. By the weekend, the incident was featured on John Oliver's HBO show (see https://www.youtube.com/watch? $\mathrm{v}=\mathrm{JMHjVSDuqvMandt=80 \textrm {s }}$ ).

Besides these initial statements of the situation and his justification for his actions, Kohen made a point to explicitly state the implications of Archer's threats, again emphasizing Archer's power and influence (and political affiliation) with using his platform and his connections within right-wing media outlets. Moreover, use of the metaphor troll storm appeals to the emotions of readers by conjuring images of natural disaster and also because troll storm is frequently used in the context of neo-Nazi discourse: 
Example (3)

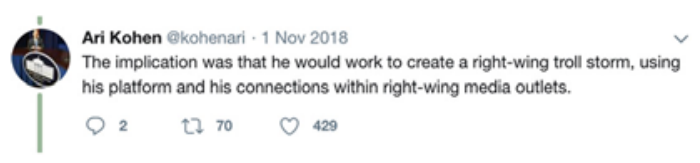

The implication was that he would work to create a right-wing troll storm, using his platform and his connections within right-wing media outlets.

\section{2 replies $\mathbf{7 6}$ retweets $\mathbf{4 4 1}$ likes}

(Kohen, 2018b)

He then frames the incident thematically, as opposed to episodically (Iyengar, 1994), pointing out (below) past consequences of similar actions at the university (and hence intertextually connecting the two incidents) as opposed to just dealing with it as one isolated event:

Example (4)

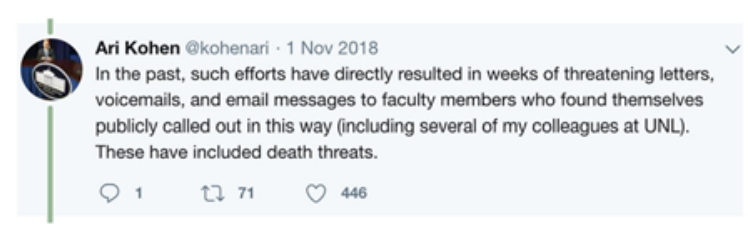

In the past, such efforts have directly resulted in weeks of threatening letters, voicemails, and email messages to faculty members who found themselves publicly called out in this way (including several of my colleagues at UNL). These have included death threats.

\section{1 reply 77 retweets 462 likes}

(Campbell, 2018)

In example (5), Kohen highlights his First Amendment rights, but then repeats the word threat, and with the word Shabbat, he highlights his status as an observant Jew (Shabbat, or Sabbath, is the weekly Jewish day of rest):

Example (5)

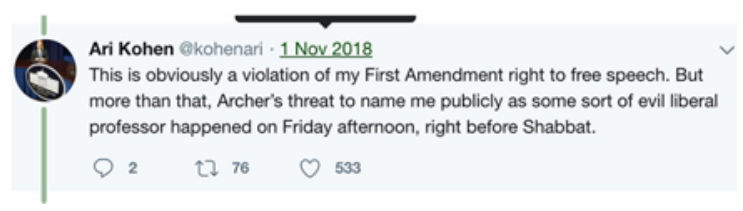


This is obviously a violation of my First Amendment right to free speech. But more than that, Archer's threat to name me publicly as some sort of evil liberal professor happened on Friday afternoon, right before Shabbat.

\section{2 replies 82 retweets 551 likes}

(Kohen, 2018d)

Through Kohen's tweets and the re-tweeting and sharing of them in numerous articles, our word frequency analysis in MAXQDA revealed 100 tokens of this word (or versions of the word such as threatened, or threaten) in a corpus of 8278 words total. Only function words (i.e. small words such as the or a and words that are not nouns, verbs, adjectives or adverbs) and the words Kohen, Archer and Fortenberry were used more frequently. This tells us that Kohen's message of the negative (and inappropriate) actions of Archer was dominant in the media discourse. In the next example, Kohen connects his Jewish background to the massacre of Jews at a synagogue in Pittsburgh that took place immediately after Archer's threatening call.

In this way, he links RWP to real life effects, again providing necessary context for the situation and more evidence as to why threats like those by Archer can lead to violent consequences:

Example (6)

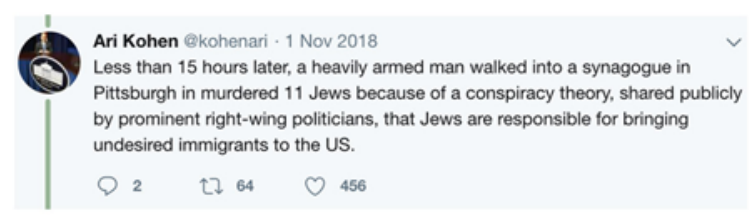

Less than 15 hours later, a heavily armed man walked into a synagogue in Pittsburgh in murdered 11 Jews because of a conspiracy theory, shared publicly by prominent right-wing politicians, that Jews are responsible for bringing undesired immigrants to the US.

\section{2 replies $\mathbf{7 0}$ retweets $\mathbf{4 7 0}$ likes}

(Kohen, 2018a)

Kohen's discourse in example (6) was necessary, because the First Amendment actually protects Archer from being responsible for any consequences of his actions (such as what would happen if he made 
good on his threats to publish Kohen's 'liking vandalism' on right-wing platforms and caused a troll storm). This is the case of Terry Jones who was not held responsible for the violent responses of his audience when he leveraged social media to spread his anti-Islamic speech around the world (Lidsky, 2011: 151). Such incidents illustrate the 'incendiary capacity of social media' and the 'mismatch between existing doctrinal categories and new types of dangerous speech', particularly in the way that offensive speech in one location can become deadly when transmitted to another (Lidsky, 2011: 147, 150). In example (7) below, Kohen connects the violence of Pittsburgh to his own community. He does this through use of deixis (me, my family, my community) which show relational identification (Van Leeuwen, 2013) and point to his personal and kinship relations as well as his social relation to the events of Pittsburgh through his Jewish identity. In addition, because of the violent actions that occurred in Pittsburgh, the history of violence against Jews, and the way that his use of deixis links this to him and his family and community, it helps him to make an emotional appeal to his audience (and connects to his earlier comment about a troll storm). Adding to this, he repeats the negative actions of Archer and not his own actions which Archer wanted to highlight and negatively portray:

Example (7)

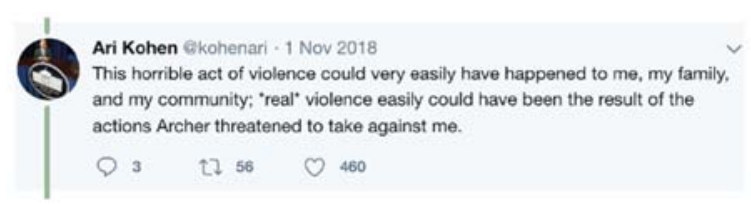

This horrible act of violence could very easily have happened to me, my family, and my community; *real* violence easily could have been the result of the actions Archer threatened to take against me.

\section{3 replies $\mathbf{6 3}$ retweets 474 likes}

(Kohen, 2018c)

Kohen chose to draw on the connection between Lincoln, Nebraska and its bestknown antisemitic citizens, Gary (Gerhard) Lauck, a major distributor of neo-Nazi literature around the world (Vaughan, 2017), and Daniel Kleve, a white supremacist student on UNL's campus who attended the Unite the Right rally in Charlottesville and displayed 
neo-Nazi banners around the state (Hayden, 2018). In the next two tweets, Kohen reemphasizes the power of Archer and Fortenberry, using it, and their negative actions (e.g. threat), to justify his filing a complaint with the Office of Congressional Ethics:

Example (8)

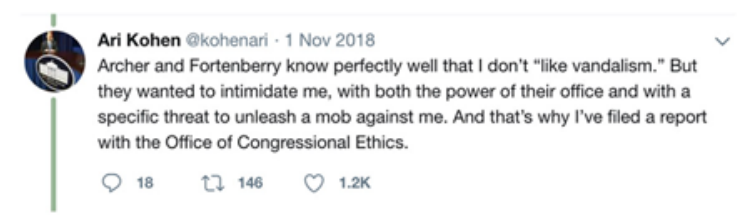

Archer and Fortenberry know perfectly well that I don't 'like vandalism'. But they wanted to intimidate me, with both the power of their office and with a specific threat to unleash a mob against me. And that's why I've filed a report with the Office of Congressional Ethics.

\section{9 replies 154 retweets 1,265 likes}

(Campbell, 2018)

In this final tweet below, Kohen again uses functionalization to focus readers on the profession of Fortenberry with the term elected officials, reminding them of the job he should be doing, instead of policing a private citizen's Facebook page. Moreover, he underscores the imbalance of power once again, by making this reference to Fortenberry's role as politician. At the same time, through use of deixis, and the 'inclusive' We, he connects himself to his readers, and to all Nebraskans who Fortenberry serves, and his use of reprehensible garbage also appeals to readers on a strong emotional level:

Example (9)

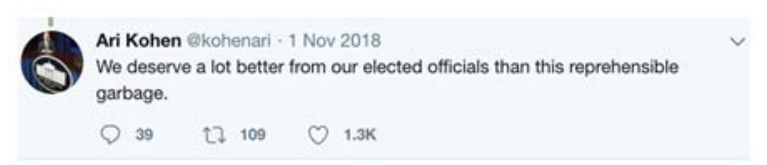

We deserve a lot better from our elected officials than this reprehensible garbage.

\section{1 replies 116 retweets 1,329 likes}

(Kohen, 2018e) 
A final linguistic strategy worth pointing out is the way Kohen refutes Archer's 'strawman fallacy' which attempts to distort his actions. Strawman fallacies are common in RWP discourse (Wodak, 2019) and function by taking a claim someone has made (in this case, Kohen's 'like' on Facebook), distorting it (e.g. saying he is liking vandalism) and then degrading or refuting it (e.g. claiming that this is not behavior suitable to a university professor and denigrating the university's reputation in the process). Even though this is not the original claim/ action, the person is then discredited in the process. Through the way that Kohen repetitively and explicitly refutes this distortion of his actions (and shared his conversation about it widely), he is successful in countering this argument before it catches on and people forget or confuse his original actions with the distorted actions that Archer attempts to accuse him of. A good example of this can be seen in this excerpt from his phone conversation with Archer (Gettys, 2018) (bolded sections are the authors', which indicate areas of focus in the analysis):

Example (10)

Kohen: ... You're going through and seeing what I have liked ...

Archer: What you're liking...

Kohen: On my private Facebook page.

Archer: I know but what you're liking is vandalism.

Kohen: No it's not.

Archer: Yes it is...

Kohen: I'm liking a photo.

Archer: You're liking what the photo represents is vandalism. If someone were liking something with Blackface, would that be acceptable? If someone were liking, you see, you've got to understand, these are icons, they're not, and they're representative of behavior. We know all this through our social learning.

Kohen: So your argument is anything that I like on Facebook represents an endorsement, by me, of the thing - not the post - but the thing that is happening in the world?

In example (10), Kohen makes explicit that the representation is not the thing itself (e.g. Rene Magritte's 'Ceci n'est pas une pipe'), as well as the multiple meaning potentials of the sign, and then shares this conversation widely through Twitter and also through multiple media 
sources. Hence, he makes the valid argument that the photograph represented a 'sophomoric' and 'silly' (Morton, 2018) photo, and nothing more. Kohen first points out the sinister nature of the fact that Archer is going through and seeing what I've liked, highlighting that this is his private Facebook page. By using the term private, he calls attention to the fact that his action of 'liking' happened in his own personal space, avoiding any connection being made to his professional space as a university professor. He essentially reiterates that even though it was a real campaign yard sign that was vandalized, it was also a photograph of that sign and there was no way for viewers to know whether this was just a photo someone made up or the real thing.

Of the linguistic strategies pointed out in this section, Kohen said he was for the most part unaware that he was doing them. However, as an early adopter of the Internet and digital native, he was conscious of his social media strategies mentioned in the previous section. And, because he knows 'what the network can do', he 'had an intuitive sense of how to get that story to go'. Kohen also said, 'There's something about having built up a little bit of cachet on that site', in that people know he is not an alarmist or conspiracy theorist and 'not just someone who is out there to just burn people down'.

In terms of his strategy of highlighting Archer's threatening actions first, he recognized the importance of showing the 'disproportionate reaction' of Fortenberry's staff linguistically. Because of the Turning Point events of the previous year, he knew that pretending he did not do something or being quiet about it did not serve anybody. He added, 'You know, when you do something, you can say you did it'. In this case, the reaction was disproportionate and wrong, so it grabbed people's attention, 'because anybody who saw the banner, whether they were conservative or liberal, thought it was funny'. So, Kohen felt that this was an easy strategy to come up with because his so-called offense was 'not an event at all in anybody's eyes' but he also did not want to put himself in the position of defending vandalism, so he knew if he highlighted what each person actually did and refuted the strawman fallacy (although he did not call it that), he could get his message across more effectively.

Finally, as regards the emotional appeal of the words/expressions he chose, Kohen said he was very aware that 
emotion moves tweets far more than any sort of intellectual agreement; when people feel a certain way as they read something - usually outrage when it comes to Twitter they're more likely to react to it and to share it with others. If they simply agree with an argument, they're more likely to 'like' it and move on.

Thus, emotional appeal appears to be an intentional strategy he used to increase coverage of the story, which added to his control of the narrative, as mentioned earlier.

Image

A final element of the media discourse about the 'googly eyes' events worth examining is visual communication. Non-verbal elements in the data included images from Kohen's tweets and from the 18 articles (including three videos) examined. In Kohen's tweets (which are reproduced in numerous articles), what is interesting to note is the profile photograph that accompanies Kohen's messages, shown in Photo 1.

In this photo, Kohen is shown sitting at what looks like a table of panelists, behind an iconic photo of the White House where it is written The White House, Washington. Although the photo is small and it is hard to see him clearly, he is shown in a demand image (when the subject gazes directly at the viewer, and in essence asks something of them) as opposed to an offer image in which he is looking off camera and in which viewers become voyeurs of the scene (Machin, 2007: 113). He is dressed in a suit and tie, and it is clear from the photo that he is important, given how he is dressed and where he is located. This might seem like nothing out of the ordinary, but Twitter profile photos can be very different ranging from classic headshots to icons that represent their political views. In the case of the 'googly eyes' events, Kohen's photo (albeit it is very small in most of the articles) worked positively for him because it represented him in a way that showed his professionalism and status. It also helped his case because his tweets were the first publicly released information about the events, and hence the tweets were reproduced in full in many of the media sources we examined, and therefore this positive image of Kohen gained a lot of traction and publicity. We tabulated visual representations across articles and determined whether these representations 
were overall positive, negative or neutral based on metonymic associations related to setting, poses, facial expressions (e.g. smile = positive, frown = negative) and distance, angle, and gaze, and whether the facial expressions occurred in a demand or offer image (Kress and van Leeuwen, 1996; Van Leeuwen, 2008). From this analysis, it is clear that Kohen had the most positive representations (13) while Archer had the least (2). In contrast, Fortenberry had the most visual representations overall (41 to Kohen's 16), 34 of which were negative (and consisted mostly of the yard sign photos in which his real eyes were replaced with googly ones). The two photos (other than the yard signs) that represented Fortenberry negatively, were both offer images, one (from Roll Call; Photo 2) showing him frowning and not gazing at the camera while the second (Newsweek; Photo 3) photo contained an upward camera angle (often representing reverence and symbolic power; Van Leeuwen, 2008). However, it was an offer image that featured him frowning as microphones were being pushed in his face by journalists.

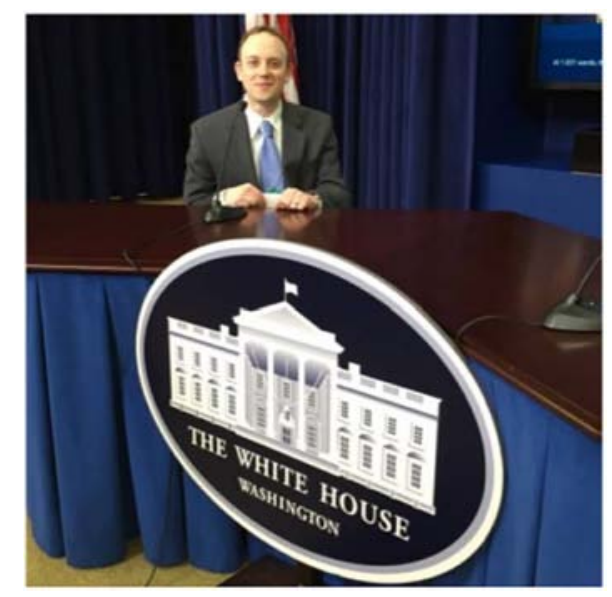

Photo 1. Kohen's Twitter profile picture. Source: Kohen (2018 a-f).

Not surprisingly, the more positive the representation of Fortenberry, the more rightleaning the news source. Those that included official government photos or images of Fortenberry smiling and looking at or speaking to the camera included the Sandhills Express (based in Norfolk, a micropolitan area surrounded by rural areas which usually votes Republican), 1011now (based in Grand Island and Kearney, more non-urban areas), and the Omaha World Herald (right-center). Oddly, The Washington Post (left-center) also had one demand 
image of Fortenberry smiling, but since it was a Twitter photo, it had to be included with the tweet they published so it is possible that is why they incorporated such a positive image. Naturally, because more left-leaning media sources published articles/videos about the 'googly eyes' events than right-leaning (which is largely due to Kohen's controlling the narrative), it is not surprising that there were more positive representations of Kohen than Fortenberry or Archer. However, it is surprising that even in right-leaning news sources, negative representations of Kohen were not present at all.

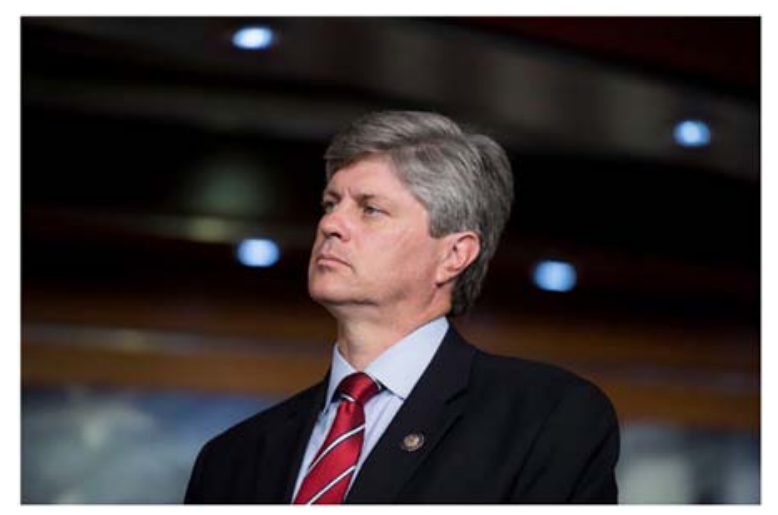

Photo 2. Rep. Jeff Fortenberry, R-Neb., participates in the news conference on a bill to repeal certain provisions on the Affordable Care Act in 2012 (credit: Bill Clark/CQ Roll Call file photo). Source: Kopp (2018).

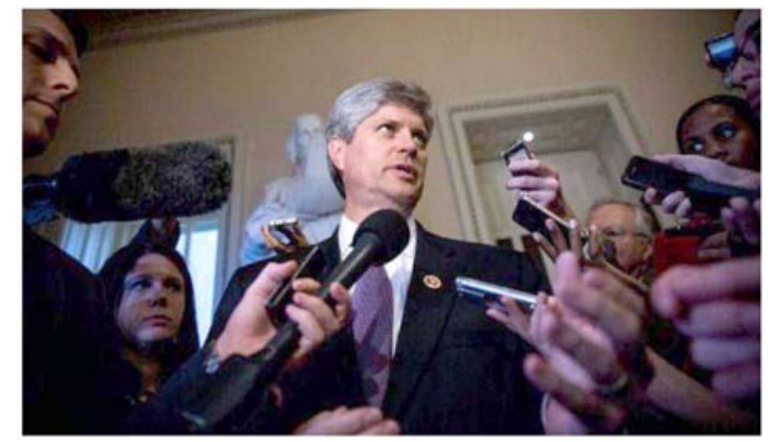

Photo 3. US Rep. Jeff Fortenberry (R-NE) walks through the Capitol Building on 15 October 2013, in Washington, DC. An associate professor who 'liked' a photo of a Fortenberry defaced campaign ad circulating on social media was allegedly threatened by Fortenberry's chief of staff (credit: Andrew Burton/Getty Images). Source: Perez (2018).

All in all, the images (namely, the 28 images of the vandalized yard sign which were widely shared) worked to forefront the ridiculousness 
of the whole incident and also connect to the powerful person behind the accusations against Kohen (e.g. Fortenberry, who was represented 34 times negatively (largely through the yard sign), 1 neutral and 6 positive). They also painted a positive picture of Kohen, whose only actions in his visual representations (16 total - 13 positive and 3 neutral) were smiling, teaching and talking. Archer, on the contrary, was shown in only two offer images (both negative) in which he is speaking into a microphone (he appears to be testifying, but the photo caption says only AP file photo; Photo 4) while his eyebrows are raised and his lips are pursed as if contesting something someone is saying (see Dunker, 2018 for the original photo).

Kohen said he did not have control over the images that were published, but as a savvy social media user, he is always careful about what photos he posts, knowing that they could be re-purposed at any point in time by someone else. As such, he did have control of the available images that people could find on the Internet of himself, again demonstrating the importance of his social media strategies in getting a positive impression of his side of the story across first. He also had some control over the fact that the yard sign was repeatedly shown in article after article (through his sharing of the tweets and Facebook posts), which put forth a ridiculous impression of Fortenberry. This is due to the silliness of the photo and also because of Fortenberry's inability to find it funny and to take a joke.

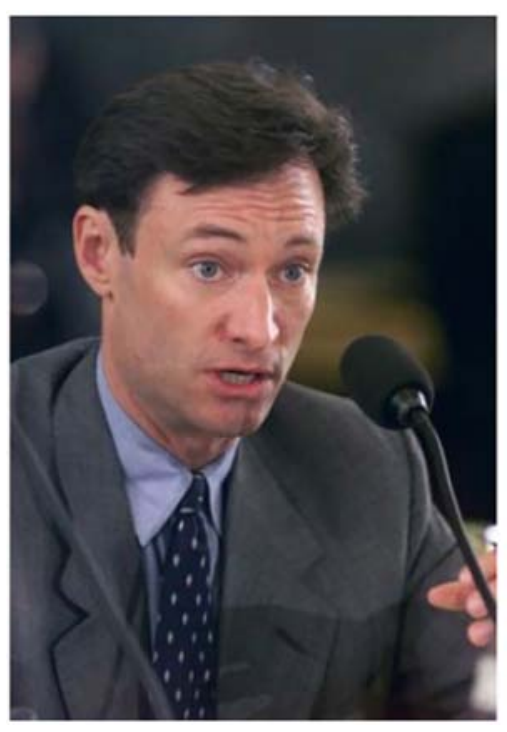

Photo 4. Archer, AP file photo. Source: Dunker (2018). 


\section{Conclusion}

This multi-layered multimodal PDA/generative critique employed CAE to analyze 18 articles (including tweets, videos and call recordings embedded in the articles) that represented the 'googly eyes' events. The goal of our article was to demonstrate constructive strategies used by Kohen to combat the right-wing attack by William 'Reyn' Archer III (acting as a proxy for Congressman Jeffrey Fortenberry). Findings revealed the use of multimodal/multimedia strategies to control the narrative (e.g. social media, framing), linguistic strategies such as use of syntax (i.e. clause placement), functionalization, and deixis, refutation of strawman fallacies (e.g. highlighting multiple meaning potentials of the sign), lexical items/tropes with emotional appeal (e.g. reprehensible garbage, troll storm) and use of image (e.g. available photos of Kohen, sharing of yard sign photo).

In conversations with Kohen, a richer understanding of the data was gained, adding nuance and depth to the way the events were represented in the media and Kohen's successful strategies in fighting back. From discussions with Kohen, we learned that his biggest asset was his social media savvy and also his knowledge of framing, which helped him know how to arrange the threads so that what he wanted people to focus on came out first. This included the image of the yard sign, as well as his tweets. He then knew how to get his message out to the most people and also to the right people (e.g. other political scientists and journalists with large readerships who would share his post widely), and he knew how to get it to focus on the negative actions of Fortenberry's staff as well as their implications. We also learned from Kohen that he has spent many years building up cachet on SNS, and he has done this through interacting with people in positive ways (e.g. engaging with his followers by having discussions with them and 'liking' things they might write to him) This network he built up through his own positive and supportive actions/words on the sites then came to his aid when needed. Kohen's style of engaging with followers is in contrast to many politicians whose posts are often onesided, meaning they are simply used to broadcast rather than to engage. That is, they post a link to a statement their staff has written or they send out a couple of sentences they want their followers to read; they usually do not engage with the people who comment on their posts or comment on the posts of others. 
In summary, we have shown the multimodal way in which Kohen was able to save his own reputation and the university's by combining a variety of strategies to explicitly reveal the nefarious intentions of Archer and Fortenberry in their attack on him. In doing so, we also provide a useful model for how this can be done for other academics worldwide who find themselves in similar anti-intellectual quandaries backed by right-wing agendas for which our article can provide not only inspiration and hope in desperate times, but concrete ways to handle such situations successfully.

Declaration of conflicting interests - The author(s) declared no potential conflicts of interest with respect to the research, authorship and/or publication of this article.

Funding - The author(s) received no financial support for the research, authorship and/or publication of this article.

\section{References}

American Freedom Radio (2016) Exclusive: How Trump won and how all can winwin now! Dr. George Lakoff on the Carol Rosin show [video file], 9 December. Available at: https://www.youtube.com/watch? $=\mathrm{drP} 9 W R c a C O 4$ (accessed 1 February 2019).

Baroni A and Mayr A (2017) 'Shared photography': (photo)journalism and political mobilisation in Rio de Janeiro's favelas. Journalism Practice 11(2-3): 285-301.

Betz HG (1994) Radical Right-Wing Populism in Western Europe. New York: St. Martins' Press.

Blackford LB (2011) Berea College professor apologizes for racially charged tweet. Lexington Herald Leader. Available at: https://www.kentucky.com/news/local/ education/article44142468.html (accessed 30 January 2019).

Campbell A (2018) Congressman Jeff Fortenberry's chief of staff threatens professor for liking Facebook post. Huffington Post, 1 November. Available at: https://www.huffingtonpost.com/entry/jeff-fortenberry-nebraska-professorthreats us 5bdb343ee4bo1abe6a1c4ca8 (accessed 20 February 2019).

Chang H, Ngunjiri F and Hernandez KAC (2016) Collaborative Autoethnography. London: Routledge.

Chouliaraki L and Fairclough N (eds) (1999) Discourse in Late Modernity: Rethinking Critical Discourse Analysis. Edinburgh: Edinburgh University Press.

Custodio L (2014): Offline dimensions of online favela youth reactions to human rights violations before the 2016 Olympics in Rio de Janeiro. In: Wood $\mathrm{N}$ (ed.) Brazil in Twenty-First Century Popular Media: Culture, Politics, and Nationalism on the World Stage. Baltimore, MD: Lexington Books, pp. 139-156. 
Dunker C (2018) Fortenberry complains about Facebook reaction to vandalized sign; UNL professor says he's bullying. Lincoln Journal Star. Available at: https://journalstar.com/news/local/education/fortenberry-complains-aboutfacebook-reaction-to-vandalized-sign-unl-professor/article ddfa4b2a-ffcf594d-9417-502fofo1cb3d.html (accessed 30 January 2019).

Fucci $\mathrm{T}$ and Catalano $\mathrm{T}$ (2019) Missing the (turning) point: The erosion of democracy at an American university. Journal of Language and Politics 18(3): 346-370.

Gettys T (2018) Lawmaker's top aide threatens public university professor for liking Facebook joke mocking his boss. The New Civil Rights Movement, 1 November. Available at: https://www.thenewcivilrightsmovement. com/2018/11/lawmakers-top-aide-threatens-public-university-professor-forliking-facebook-joke-mocking-his-boss/ (accessed 1 February 2019).

Haraway DJ (1997) Modest_witness@second_millennium.femaleman_meets_ oncomouse. New York: Routledge.

Hayden ME (2018) Nebraska White supremacist who praises violence poses unique challenges to campus free speech. Newsweek, 13 February. Available at: https://www.newsweek.com/nebraska-white-supremacist-unique-challengescampus-free-speech-804442 (accessed 30 January 2019).

Hofstadter R (1963) Anti-Intellectualism in American Life (3. Print.), vol. 713. New York: Vintage.

Hudson DL (2018) Free speech on public college campuses overview. Freedom Forum Institute. Available at: https://www.freedomforuminstitute.org/firstamendment-center/topics/freedom-of-speech-2/free-speech-on-public-collegecampuses-overview/ (accessed 30 January 2019).

Iyengar S (1994) Is Anyone Responsible? How Television Frames Political Issues. Chicago, IL: University of Chicago Press.

Kelsey D and Bennet L (2014) Discipline and resistance on social media: Discourse, power and context in the Paul Chambers 'Twitter Joke Trial'. Discourse, Context, Media 3: 37-45.

Kingkade T (2013) Geoffrey Miller censured by University of New Mexico for lying about fatshaming tweet. Huffington Post. Available at: http://www. huffingtonpost.com/2013/08/07/geoffrey-miller-censured-unm n 3716605. html (accessed 30 January 2019).

Kohen A (2018a) Less than 15 hours later, a heavily armed man walked into a synagogue in Pittsburgh in murdered 11 Jews because of a conspiracy theory, shared publicly by prominent right-wing politicians, that Jews are responsible for bringing undesired immigrants to the US, 1 November. Available at: https:// twitter.com/kohenari/status/1057989081156730881 (accessed 30 January 2019).

Kohen A (2018b) The implication was that he would work to create a rightwing troll storm, using his platform and his connections within right-wing media outlets, 1 November. Available at: https://twitter.com/kohenari/ status/1057989081156730881 (accessed 30 January 2019). 
Kohen A (2018c) This horrible act of violence could very easily have happened to me, my family, and my community; *real* violence easily could have been the result of the actions Archer threatened to take against me, 1 November. Available at: https://twitter.com/kohenari/status/1057989081156730881 (accessed 30 January 2019).

Kohen A (2018d) This is obviously a violation of my First Amendment right to free speech. But more than that, Archer's threat to name me publicly as some sort of evil liberal professor happened on Friday afternoon, right before Shabbat, 1 November. Available at: https://twitter.com/kohenari/ status/1057989081156730881 (accessed 20 January 2019).

Kohen A (2018e) We deserve a lot better from our elected officials than this reprehensible garbage, 1 November. Available at: https://twitter.com/ kohenari/status/1057989081156730881 (accessed 30 January 2019).

Kohen A (2018f) You can read about what happened in this article in today's Lincoln Journal- Star. Archer tells the reporter that he didn't threaten me, 1 November. Available at: https://journalstar.com/news/local/education/ fortenberry-complains-about-facebook-reaction-to-vandalized-sign-unlprofessor/article_ddfa4b2a-ffcf-594d-9417-502fofo1cb3d.html?mode=nowapp (accessed 30 January 2019).

Kopp E (2018) Feud over professor's Facebook 'like' prompts complain against Fortenberry Chief of Staff. Roll Call. Available at: https://www.rollcall. com/news/politics/jeff-fortenberry-chief-staff-facebook-like (accessed 3 September 2019).

Kress G and van Leeuwen T (1996) Reading Images: The Grammar of Visual Design. London: Routledge.

Krzyżanowski M (2011) Ethnography and critical discourse analysis: Towards a problem-oriented research dialogue. Critical Discourse Studies 8(4): 231-238.

Krzyżanowski M and Tucker JA (2018) Re/constructing politics through social and online media. Journal of Language and Politics 17(2): 141-154.

Lakoff G (2006) Thinking Points: Communicating Our American Values and Vision. London: Macmillan.

Lakoff G (2014) The All New Don't Think of an Elephant! Know Your Values and Frame the Debate. Chelsea, VT: Chelsea Green Publishing.

Lakoff G and Wehling E (2012) The Little Blue Book: The Essential Guide to Thinking and Talking Democratic. New York: Simon \& Schuster.

Lidsky LB (2011) Incendiary speech and social media. Texas Tech Law Review 44: 147.

Liptak A (2018) How conservatives weaponized the First Amendment. The New York Times. Available at: https://www.nytimes.com/2018/06/30/us/politics/ first-amendment-conservatives-supreme-court.html (accessed 19 February 2019).

Macgilchrist F (2016) Fissures in the discourse-scape: Critique, rationality and validity in postfoundational approaches to CDS. Discourse and Society 27(3): 262-277. 
Machin D (2007) Introduction to Multimodal Analysis. New York: Bloomsbury Publishing.

Machin D and Mayr A (2012) How to Do Critical Discourse Analysis: A Multimodal Introduction. London: SAGE.

Martin JR (2004) Positive discourse analysis: Solidarity and change. Revista Canaria de Estudios Ingleses 49(1): 179-202.

Mayr A (2018) Rioting and disorderly behavior as political media practice on the stress of L.A. during the riots of 1992. In: Kelsey D and Hart C (eds) Discourses of Disorder: Riots, Strikes and Protests in the Media. London: Edinburgh University Press.

Miller MH (2010) East Stroudsburg U. suspends professor for Facebook posts. The Chronicle of Higher Education. Available at: http://chronicle.com/blogs/ wiredcampus/east-stroudsburgu-suspends-professor-for-facebook-posts (accessed 1 February 2019).

Mortensen M (2011) When citizen photojournalism sets the news agenda: Neda Agha Soltan as a Web 2.0 icon of post-election unrest in Iran. Global Media and Communication 7(1): 4-16.

Morton J (2018) UNL professor files ethics complaint, alleging Fortenberry's chief of staff threatened him over Facebook post. Kearney Hub. Available at: https://www.kearneyhub.com/news/state/unl-professor-files-ethicscomplaint-alleging-fortenberry-s-chief-of/article 297fd1ba-debb-11e8-bdcd175f53473992.html (accessed 20 February 2019).

Perez M (2018) Professor claims he was threatened by Congressman's Chief of Staff for 'liking' vandalized 'Fartenberry' sign on Facebook. Newsweek. Available at: https://www.newsweek.com/congressman-chief-staff-allegedlythreatened-professor-vandalized-fartenberry-1197840 (accessed 3 September 2019).

Rogers R (2002) Through the eyes of the institution: A critical discourse analysis of decision making in two special education meetings. Anthropology and Education Quarterly 33(2): 213-237.

Saldana J (2015) The Coding Manual for Qualitative Researchers. London; New York: SAGE.

Scott JW (2017) On Free Speech and Academic Freedom. AAUP Journal of Academic Freedom 8: 1-13.

Siniver A (2016) Anti-intellectualism and Israeli politics. British Journal of Middle Eastern Studies 43(4): 630-643.

Stein B (2013) Court rules that Facebook likes are free speech. ACLU. Available at: https://www.aclu.org/blog/free-speech/court-rules-facebook-likes-are-freespeech (accessed 1 February 2019).

Sugimoto C, Hank C, Bowman T, et al. (2015) Friend or faculty: Social networking sites, dual relationships, and context collapse in higher education. First Monday 20(3). Available at: https://firstmonday.org/article/view/5387/4409

Tiede HJ (2017) Exhuming McCarthy: Meet me at the book burning. American Association of University Professors. Available at: https://www.aaup.org/ comment/3979\#.W2ONPBpKg U 
Van Leeuwen T (2008) Discourse and Practice: New Tools for Critical Discourse Analysis. New York: Oxford University Press.

Van Leeuwen T (2013) The representation of social actors. In: Caldas-Coultard CR and Coulthard M (eds) Texts and Practices: Readings in Critical Discourse Analysis. London: Routledge, pp. 41-79.

Vaughan C (2017) The farm belt fuhrer: The making of a neo-Nazi. The Guardian, 6 July. Available at: https://www.theguardian.com/world/2017/jul/o6/neonazi-gerhard-lauck-nebraska-antisemitism (accessed 30 January 2019).

Vertuno J (2000) Texas health official on paid leave. The Washington Post, 19 October. Available at: http://www.washingtonpost.com/wp-srv/ aponline/20001019/aponline194937 000.htm (accessed 1 February 2019).

Weiner S (2018) Rep. Jeff Fortenberry's chief of staff threatened a professor over liking a defaced sign on Facebook. Splinter News, 1 November. Available at: https://splinternews.com/repjeff-fortenberrys-chief-of-staff-threatened-aprof-1830167147 (accessed 20 February 2019).

Wodak R (1996) Disorders of Discourse. London: Longman.

Wodak R (2009) The Discourse of Politics in Action: Politics as Unusual. London: Palgrave Macmillan.

Wodak R (2015) The Politics of Fear: What Right-wing Populist Discourses Mean. London: SAGE.

Wodak R (2017) The 'establishment', the 'elites', and the 'people'. Who's who? Journal of Language and Politics 16(4): 551-565.

Wodak R (2019) Entering the 'post-shame era': The rise of illiberal democracy, populism and neoauthoritarianism in Europe. Global Discourse 9(1): 195-213.

Wodak R and Krzyżanowski M (2017) Right-wing populism in Europe and USA. Journal of Language and Politics 16(4): 471-484.

Zakaria F (1997) The rise of illiberal democracy. Foreign Affairs 76(6): 22-43.

\section{About the Authors}

Theresa Catalano is Associate Professor of Second Language Education/Applied Linguistics at the University of Nebraska-Lincoln. Her research focuses on language and migration, language education and (multimodal) critical discourse studies. Her recent book Talking about Global Migration was published in 2016 by Multilingual Matters. She teaches graduate/undergraduate courses on multimodal discourse analysis, linguistics, intercultural communication and (dual) language education.

Ari Kohen is Associate Professor of Political Science and Schlesinger Professor of Social Justice at the University of Nebraska-Lincoln. His most recent book, Untangling Heroism: Classical Philosophy and the Concept of the 
Hero was published by Routledge in 2014. His first book, In Defense of Human Rights: A Non-Religious Grounding in a Pluralistic World, also from Routledge, was published in 2007. In addition to a dozen articles on human rights, heroism and restorative justice, Kohen is also co-editor of a new series of edited volumes on contemporary research and teaching on the Holocaust from the University of Nebraska Press. 